\title{
PUHEENVUORO
}

\section{EPIDEMIAHISTORIA MEDIASSA \\ KEVÄÄN JA KESÄN 2020 AIKANA}

\author{
HEINI HAKOSALO \& ANNASTIINA MÄKILÄ
}

Pohjois-amerikkalaiset lääketieteen historioitsijat puhuivat SARS-epidemian aikaan (2003) "Thukydides-indeksistä”. Termi kuvaa sitä, miten akuutti tartuntatautiepidemia tai sellaisen uhka lisää tutkijoiden, toimittajien ja yleisön kiinnostusta tautihistoriaan. Kiinnostus ilmenee yllättävinä piikkeinä viittausindekseissä, esimerkiksi viittauksina sellaisiin hahmoihin kuin Thukydides, joka kirjoitti tunnetun kuvauksen"Ateenan rutosta" 430 eaa. (Duffin 2006, 4.) Vakava epidemiauhka muuttaa asioiden tärkeysjärjestystä ja nostaa median agendalle ilmiöitä, myös historiallisia ilmiöitä, joita siellä muuten harvoin näkyy. Tässä puheenvuorossa kysytään miten tautihistoriasta puhuttiin mediassa koronan ensimmäisen aallon eli kevään ja kesän 2020 aikana $^{1}$ ja millaisia tarkoituksia historiapuhe palveli.

Puheenvuoromme perustuu media-aineiston laadulliseen analyysiin. Haravoimme systemaattisesti tautihistoriaan liittyviä sisältöjä seuraavista medioista: Helsingin Sanomat, Hufoudstadsbladet ja Suomen Kuvalehti, YLE uutisten nettisivu, Dagens Nybeter, Guardian UK edition, Die Zeit, New York Times. Hakusanoina toimivat esimerkiksi "historia+sairaudet" ja "kulkutaudit". Edustettuna on johtavia sanomalehtiä viidestä maasta ja neljältä kielialueelta. Suomesta on suurimpien suomen- ja ruotsinkielisten päivälehtien lisäksi mukana yksi yleisaikakauslehti ja yksi uutissivusto. Media-aineistoon valikoituneita tekstejä on yhteensä 270. (Taulukko 1.) Lisäksi seurasimme vähemmän systemaattisesti epidemiahistoriallista kirjoittelua muissa medioissa. Keskitymme aineistosta nouseviin havaintoihin, sillä tätä nimenomaista aihetta ei vielä ole tutkittu muutamia suppeita puheenvuoroja lukuun ottamatta (Charters \& MacKay 2020; Jones 2020b). ${ }^{2}$

Määrällinen kasvu oli ilmeistä eikä rajoittunut valtavirtamediaan. Kulkutautien historia

TAULUKKO 1. MEDIA-AINEISTO

\begin{tabular}{lllc} 
NIMI & LYHENNE & JULKAISUMAA & TEKSTEJÄ \\
\hline Dagens Nyheter & DN & Ruotsi & 34 \\
\hline Guardian UK edition & Guardian & Iso-Britannia & 30 \\
\hline Helsingin Sanomat & HS & Suomi & 41 \\
\hline Hufvustadsbladet & HBL & Suomi & 16 \\
\hline New York Times & NYT & USA & 68 \\
\hline Suomen Kuvalehti & SK & Suomi & 17 \\
\hline YLE uutiset (nettisivu) & YLE & Suomi & 24 \\
\hline Die Zeit & ZEIT & Saksa & 24 \\
\hline YHTEENSÄ & & & 254
\end{tabular}


oli esillä tavallista enemmän myös blogeissa ja sosiaalisessa mediassa, ja osa tiedekustantajistakin reagoi tilanteeseen nopeasti, kooten jo julkaistusta tai uudesta materiaalista epidemiahistoriallisia erikoisnumeroita (esim. Wallis ym. 2020, History of Outbreaks Collection, Charters \& Vermeir 2020). Tutkimusperustaista keskustelua tartuntatautien historiasta käytiin myös sellaisilla sähköisillä alustoilla kuin History E Policy ja History Workshop. Lääketieteellisistä julkaisuista esimerkiksi Lancet ja New England Journal of Medicine antoivat epidemian alkuvaiheessa puheenvuoron historioitsijoille (Jones 2020a; White 2020; Strasser \& Schlich 2020; Honigsbaum 2020). Museot, arkistot, järjestöt ja tutkimusryhmät kutsuivat ihmisiä lähettämään kirjoituksia, esineitä ja valokuvia korona-ajalta. Media esitteli muistiorganisaatioiden keräyshankkeita suurelle yleisölle ja keräsi itsekin aineistoa. New York Times kannusti lukijoitaan pitämään koronapäiväkirjaa: "Se auttaa sinua järjestämään ajatuksiasi näinä vaikeina aikoina ja voi auttaa opettamaan tulevia sukupolvia" (NYT 13.4.). Mittavan keräystoiminnan nopea käynnistäminen oli omiaan vahvistamaan mielikuvaa, että elettiin historiallisia aikoja.

\section{MISTÄ TAUDEISTA PUHUTTIIN?}

Menneistä tautiepidemioista eniten mediakiinnostusta keräsi vuosien 1918-20 influenssaepidemia eli espanjantauti. Taudin arvellaan tappaneen jopa 50-100 miljoonaa ihmistä, mikä tekee siitä absoluuttisella kuolleisuudella mitattuna historian todennäköisesti tuhoisimman tautiepidemian. Pandemian taloudelliset ja yhteiskunnalliset vaikutukset jäivät kuitenkin suhteellisen pieniksi (Crosby 1976), eikä epidemiaa juuri kirjallisuudessa tai mediassa muisteltu ennen vuosituhannen vaihdetta, jolloin lintuinfluenssa (1997), sikainfluenssa (2009) ja pandemian satavuotismuisto (1918) toivat sen parrasvaloihin. Koronan puhjetes- sa espanjantauti ei enää ollut samalla tavalla "unohdettu pandemia", kuin se oli ollut vielä 1900-luvun lopulla, ja korona-aika vahvisti entisestään sen asemaa kollektiivisessa muistissa.

Espanjantaudista puhuivat kaikki tarkastelemamme mediat, ja aivan erityisen usein New York Times, jossa pandemia oli maalishuhtikuussa esillä lähes päivittäin. Helsingin Sanomat ja Suomen Kuvalehti julkaisivat laajat espanjantauti-aiheiset artikkelit (HS Kuukausiliite, huhtikuu; SK 18.3.). Suhteellisen hiljattaista historiallista epidemiaa oli helppo tarkastella buman interest -näkökulmasta ja kuvittaa juttuja valokuvilla, kirje- ja päiväkirjakatkelmilla, muistietoaineistolla ja jopa haastatteluilla. Vaikka virus on erilainen, moni muu asia tuntui yhdistävän vuosien 1918 ja 2020 epidemioita: tartuntatapa, osa oireista sekä keinot, joilla tartunnan leviämistä lääkkeiden ja rokotteiden puuttuessa koetettiin rajoittaa. Se, että espanjantauti levisiä kolmena aaltona, joista toinen oli pahin, antoi aihetta pahoihin aavistuksiin. Koronan toistuva vertaaminen espanjantautiin toimi eräänlaisena hälytyssignaalina, muistutuksena siitä, että koronasta voi tulla espanjantaudin kaltainen suurtappaja.

Muut historialliset influenssapandemiat talven 1889-90 "venäjänkuume", talven 195758 "aasialainen" ja talven 1968-69 "hongkongilainen" - saivat mediassa vähemmän huomiota. Niitä tarkasteltiin usein henkilöhistoriallisesta näkökulmasta. Guardian kertoi venäjänkuumeen tappaneen kuningatar Viktorian perillisen ja pohti olisiko taudin aiheuttaja itse asiassa voinut olla koronavirus (26.5.). 1900-luvun jälkipuoliskon influenssapandemioita käsittelevissä kirjoituksissa haastateltiin usein ihmisiä, jotka olivat joko sairastaneet taudin tai hoitaneet siihen sairastuneita. Moni kertoi, ettei influenssapandemioista aikanaan tehty suurta numeroa, ja antoi ymmärtää, että asenteesta voisi ottaa oppia. (Guardian 1.5.; HBL 24.3.; NYT 28.3., 22.3.). Lääketieteen historioitsija Mark Honigsbaumin (2020) artikkeli Lancetissa oli ainoa 1900-luvun jälki- 
puoliskon influenssapandemioihin keskittyvä tutkimusperustainen teksti aineistossamme.

Eri epidemiat antoivat mahdollisuuden nostaa esiin koronan kanssa eri tavoin resonoivia teemoja. Esimerkiksi mustaa surmaa, eli sydänkeskiajan ruttoepidemian ensimmäistä aaltoa, käsittelevissä artikkeleissa korostettiin valtavaa väestökatoa ja laajoja taloudellisia ja yhteiskunnallisia vaikutuksia ja kerrottiin karanteenitoimien historiallisista juurista. Ruton jälkiä etsittiin ja löydettiin taiteesta, kirjallisuudesta ja kulttuurista. (DN 12.5.; Guardian 26.2.; HS 22.3.; HBL 29.3.; SK 6.3.; NYT 5.4.; Zeit 19.3.) Isorokon historia antoi tilaisuuden puhua rokotteista ja muistuttaa, että ainakin yksi vaarallinen tauti oli saatu rokottamalla hävitettyä. Keltakuumeen historia oli myös orjakaupan ja rotusorron historiaa, ja kiinnostus siihen kasvoi kesällä, Black Lives Matter -mielenosoitusten aikaan. Koleran historia puolestaan tarjosi esimerkkejä epätasa-arvoisesta tavasta, jolla epidemiat ovat kohdelleet eri yhteiskuntaluokkia ja kansoja, ja muistutti kansainvälisen terveysalan yhteistyön merkityksestä. Lavantautiaiheisten artikkelien keskiössä oli "supertartuttaja" Mary Mallon eli "lavantauti-Mary". Polioepidemioita muisteltiin erityisesti USA:ssa. Koronaa ja poliota yhdistävät ainakin karanteenitoimet, hengityskoneet ja kilpajuoksu rokotteen löytämiseksi."Jälkipolio" eli vuosikymmeniä taudin akuutin vaiheen jälkeen ilmaantuvat etenevät oireet antoivat aiheen spekuloida "jälkikoronan" mahdollisuudella. (DN 25.4.; Guardian 26.5., 20.3.; NYT 16.3., 12.4.; Atlantic 29.3., 16.4.; Daily Mail 22.8.; LRB 7.5.; HS 11.5.; Zeit 1.4.; LRB 28.7.; Conversation 6.6.; Economist 11.4.; SK 31.3.)

Tautihistoriallisia artikkeleita ilmestyi eniten maalis-huhtikuussa. Alussa niiden sävy oli usein dramaattinen ja ote kokonaisvaltainen. Pandemian ensimmäisen, dramaattisen vaiheen jälkeen aiheet "pienenivät" ja painopiste siirtyi epidemioiden aiheuttamista tuhoista siihen, miten epidemia-aikoina elettiin. Lehdet kirjoittivat esimerkiksi kasvomaskien, suoja-asujen ja käsienpesun historiasta sekä kertoivat, miten espanjantaudin aikana vietettiin häitä tai urheiltiin, käytiin teatterissa ja nautittiin musiikista. (NYT 17.3.; DN 16.5.; Guardian 11.3.; HS 5.4.; Economist 1.8.). New York Times Magazine julkaisi laajan artikkelin ruuasta ja syömisestä historiallisten epidemioitten aikana (16.7.). YLE ja Helsingin Sanomat kertoivat, mistä kriisiaikoina on revitty huumoria ja miten kulutettu aikaa (YLE 12.4.; HS 27.4.). Kevään edetessä etsittiin yhä useammin vastauksia siihen, miten epidemiat loppuvat ja millaisia seurauksia niillä on ollut. Mediassa viitattiin usein näkemykseen, jonka mukaan epidemiat loppuvat joko biologisesti, kun riittävän suurella osalla väestöstä on rokottamalla tai sairastamalla saatu immuniteetti, tai sosiaalisesti, kun ihmiset sopeutuvat taudin läsnäoloon ja lakkaavat kokemasta sitä eksistentiaalisena uhkana. (NYT 10.5.; YLE 10.4.; HS 23.5.)

Suurten epidemioiden historia on pitkälti ihmiskunnan yhteistä historiaa, mutta median tavassa puhua tautien historiasta oli myös kansallisia painotuseroja. Siinä missä USA:ssa kirjoitettiin keltakuumeen historiasta, Suomessa ja Sveitsissä muisteltiin, millaista pelkoa suu- ja sorkkatauti herätti maatalousvaltaisissa maissa 1950-luvulla. Myös 1980- ja 1990-lukujen AIDS-epidemia sai mediatilaa ja aktivistit äänensä kuuluviin. (Zeit 10.4., 4.5.; HS 3.4.; NYT 28.3., 18.6.; Guardian 6.4.). Aiheenvalinnan ohella kansallisia eroja näkyi siinä, millaiseen historialliseen viitekehykseen koronapandemia asetettiin. Englanninkielisessä lehdistössä historioitsijoiden tavassa hahmottaa epidemihistoriaa näkyi usein historioitsija Charles Rosenbergin aikoinaan hahmotteleman epidemianarratiivin vaikutus. Siinä epidemian ensimmäistä vaihetta leimaavat hienovaraiset merkit, joita useimmat ihmiset kieltätyvät näkemästä, toista tautiuhan tiedostaminen ja vastausten ja radikaalien toimenpiteiden vaatiminen, kolmatta jonkinasteinen sopeutuminen. (Rosenberg 1989.) 
Suomessa koronaa käsiteltiin usein laajemman kriisihistorian viitekehyksessä. Pandemia-aikaa verrattiin nälkävuosiin, taloudellisiin lamakausiin, sisällissodan ja espanjantaudin aikaan ja ennen kaikkea toisen maailmansodan aikaan. Niin toimittajat kuin heidän haastattelemansa asiantuntijatkin löysivät lukuisia samankaltaisuuksia korona-ajan ja sota-ajan välillä. Maaliskuussa tilannetta verrattiin talvisodan aaton tunnelmiin, huhtikuussa asemasotaan. Toukokuussa ennakoitiin, että koronaa, kuten sotaa, seuraa sekä rikosaalto että piikki syntyvyydessä. (YLE 18.3., 4.4.; HS 2.4., 27.4., 1.5., 7.5.; SK 23.5.) Sodan asemaa keskeisenä ja lähes itsestään selvänä viittauskohtana selittänee toisen maailmansodan keskeinen asema sekä suomalaisessa historiografiassa että kollektiivisessa muistissa ja identiteetissä. Myös sotametaforiikan runsas viljeleminen hyväksyttiin Suomessa - toisin kuin Ruotsissa, Iso-Britannissa tai USA:ssa lähes ilman soraääniä. ${ }^{3}$

\section{HISTORIAN OPETUKSET}

Miksi historiasta puhuttiin korona-aikana niin paljon? Millaisiin tarpeisiin se vastasi? Journalismin käytännöt ja mahdollisuudet muuttuivat keväällä dramaattisesti, kun yksi uutinen ohitti kaikki muut. Historia-aiheinen sisältö ei kuitenkaan ollut pelkkää palstantäytettä, vaan myös yritys vastata poikkeustilan synnyttämiin tarpeisiin ja sen herättämiin kysymyksiin. Koronan leviäminen pandemiaksi oli akuutti kollektiivinen kriisi, ja kriisi merkitsee määritelmällisesti radikaalia epävarmuuden tila. Kun tulevaisuus oli auki, menneisyys, se mitä oli jo tapahtunut ja minkä seuraukset olivat jo nähtävissä, edusti omalla tavallaan varmuutta ja turvallisuutta.

Ensinnäkin historiapuhe oli keino suhteuttaa ja suhteellistaa koronapandemiaa. Koronan iskiessä vain harvoilla vauraiden teollisuusmaiden asukkaista oli omakohtaista kokemus- ta pandemioista. Ihmisten mielissä pandemiat kuuluivat historiaan, ja uhan vakavuutta pyrittiin arvioimaan historian valossa. Havainnollisin suhteuttamisen tapa olivat aikajanat, kaaviot ja infografiikat, joissa historian suurimpia epidemioita tarkasteltiin rinnakkain yleensä kahden muuttujan - ajan ja kuolleisuuden valossa. ${ }^{4}$ Näissä esityksissä epidemian suuruuden ja samalla sen historiallisen merkityksen tärkein mittari oli kokonaiskuolleisuus. Myös ajallinen etäisyys saattoi toimia mittarina: mitä kauempaa lähin vertailukohta löytyi, sitä harvinaisemmasta ja "historiallisemmasta" ilmiöstä oli kyse. Ruotsin tilastokeskuksen edustaja totesi toukokuun puolivälissä, että ylikuolleisuus oli viimeksi ollut samalla tasolla vuonna 1918, siis espanjantaudin aikaan (DN 17.5.). Helsingin Sanomat kertoi, että muslimien suuri pyhiinvaellus Mekkaan oli edellisen kerran peruutettu Napoleonin sotien aikana (3.4.). Ennakoitu talouden taantuma kirvoitti runsaasti historiallista vertailua. Koronakriisiä verrattiin 1930-luvun lamaan, öljykriisiin (1970-luku) ja finanssikriisin (2007-09), Suomessa usein myös 1990-luvun lamaan. Moni taloushistorioitsija tosin korosti myös koronakriisin erikoispiirteitä. (Guardian 12.8.; HS 25.3.; YLE 15.4.)

Suhteuttaminen voi vaikuttaa neutraalilta tavalta nojata historiaan, mutta samoista luvuista voi tunnetusti vetää erilaisia johtopäätöksiä. Usein toimittaja opasti lukijaa oikeanlaiseen tulkintaan. Dagens Nybeterin Magnus Västerbro katsoi historiallisen vertailun osoittavan, että"Paniikkituntemukset [...] eivät tämän päivän tilanteessa ole mikään perusteltu reaktio" (DN 9.2., 12.3.). Suhteuttamisessa on myös riskinsä. Lääkäri ja historioitsija David Jones käsitteli maaliskuussa New England Journal of Medicinessä julkaisemassaan artikkelissa historian suuria epidemioita ja totesi koronakuolleisuuden ainakin toistaiseksi jäävän kauas niiden aiheuttamasta kuolleisuudesta. Hän sai ankarat moitteet lääkäriltä, joka kamppaili saadakseen hallinnon ja kansalaiset ottamaan pandemiauhan tosissaan ja koki Jo- 
nesin suhteellistamisyrityksen vetävän mattoa jalkojensa alta. (Jones 2020b, 376.) Latautuneessa tilanteessa suhteuttaminen voidaan tulkita pandemiauhan tai kanssaihmisten pelon vähättelemiseksi.

Toiseksi historiasta haettiin valaisevia, hätkähdyttäviä tai viihdyttäviä analogioita. $\mathrm{Ne}$ ovat historiasta ammentavan journalismin peruselementti. Jos lehti pandemian juuri puhjettua kirjoittaa 700 vuoden takaisesta ruttoepidemiasta, on selvää, että kyseessä ei ole sattuma, vaan kutsu verrata pandemioita keskenään. Jo helmikuun puolivälissä New York Times otsikoi Wuhanin olevan "kuin Eurooppa keskiajalla" (NYT 10.2.2020) ja samanlaisia rinnastuksia tehtiin pitkin kevättä ja kesää. Samankaltaisuuksia löydettiin etenkin siitä, miten yksilöt, yhteisöt ja yhteiskunnat ovat eri aikoina reagoineet epidemioihin, esimerkiksi miten huhut ja salaliittoteoriat ovat päässeet valloilleen pandemian ensi vaiheessa. Tiedetoimittaja Gina Kolatan mukaan merkittävin samankaltaisuus vuoden 1918 (espanjantaudin) ja kevään 2020 (koronan) välillä oli "kollektiivisen huolen sävy"(NYT 9.3.) Historialliset analogiat ovat mediassa niin tavallisia, että niitä tuskin huomaa. Niillä on kuitenkin voimaa ohjata ajattelua, tunteita ja toimintaa, tukea tai kyseenalaistaa toimintalinjoja. $\mathrm{Ne}$ tuovat historian lähelle muistuttamalla, että ihmiset ovat painineet samankaltaisten ongelmien kanssa aiemminkin, ja vahvistavat mielikuvaa, että historia kaikesta huolimatta jollakin tasolla toistaa itseään.

Kolmanneksi historiasta etsittiin varoittavia ja kannustavia esimerkkejä, ennakkotapauksia ja toimintamalleja. Sanat "lesson" ja "teach" olivat tavallisia englanninkielisten lehtien historia-aiheisten artikkelien otsikoissa. Myös Zeit ja Dagens Nybeter olivat otsikoiden perusteella vakuuttuneet historian kyvystä "opettaa", "paljastaa" ja "osoittaa" asioita. Suomalaisessa aineistossa tällaisia otsikoita ei juuri näkynyt joko kielellisistä tai muista syistä. Median historiasta löytämät opetukset olivat useimmiten moraalisia, yhteiskunnallisia tai poliittisia. $\mathrm{Ne}$ saattoivat olla suuria ja periaatteellisia, kuten silloin kun Guardian etsi historiasta vastausta kysymykseen "Miten voimme rakentaa oikeudenmukaisemman yhteiskunnan pandemian jälkeen?” (14.8.), tai pienempiä ja konkreettisempia, kuten Nerw York Timesin toimittajan suositellessa, sadan vuoden takaiseen esimerkkiin vedoten, että koululaiset vietäisiin korona-aikana ulos oppimaan. (NYT 17.7.)

Ainakin yhdessä tapauksessa "historian oppien" voi katsoa suoraan vaikuttaneen koronan vastaisiin toimiin. Historioitsija $\mathrm{Ho}^{-}$ ward Markel ja epidemiologi Carter Mecher ryhmineen tutkivat 2000-luvun alussa, miten karanteenitoimet eri puolilla Yhdysvaltoja vaikuttivat kuolleisuuteen vuonna 1918. Ryhmät päätyivät tahoillaan samaan tulokseen: nopeat ja tiukat karanteenitoimet vähensivät kuolleisuutta. (Markel ym. 2007; Hatchett, Mecher \& Lipsitch 2007.) Tulokset huomioitiin USA:n kansallisissa valmiussuunnitelmissa, ja kun sulku- ja karanteenipäätöksiä tehtiin koronaajan alussa, ne nostettiin näkyvästi esiin mediassa, missä ne muokkasivat yleistä mielipidettä rajoituksia suosivaan suuntaan. (Jones 2020b, 374; NYT 17.3., 1.4., 3.4.; NYRB 17.3.; Economist 31.3.; National Geographic 27.3.; PBS 20.4.) Tutkimukset saivat lisätukea, kun ryhmä taloustieteilijöitä osoitti, että ne USA:n kaupungit, joissa oli vuosina 1918-19 harjoitettu määrätietoisia rajoitustoimia, olivat selvinneet pandemiasta paremmin myös taloudellisesti. (Correia, Luck \& Verner 2020; NYT 3.4.) Tutkimusten uutisointi oli vahva kannanotto maassa, jossa rajoitustoimet herättivät paikoin raivokasta vastarintaa ja jossa vastustajat vetosivat nimenomaan näiden toimien taloudelle muodostamaan uhkaan.

Neljänneksi menneisyyden avulla koetettiin ennakoida tulevaa. Moni mediassa esiintynyt historioitsija korosti, että pandemioilla oli historian kuluessa ollut laajamittaisia seurauksia. Kun historioitsija totesi jonkin asian seuranneen pandemioita "usein" tai "aina”, hän avasi samalla oven historiaperustaiselle ennustamiselle. Harva historioitsija oli kuitenkaan 
valmis itse astumaan tästä ovesta. Jopa sellaiset maailmanhistorian suurten linjojen hahmottajat kuin Jared Diamond ja Yuval Noah Harari tyytyivät keväällä ilmaisemaan lähinnä huoliaan ja toiveitaan. (Zeit 7.4.; HS 11.4.; Guardian 20.4.; DN 20.3.; FT 20.3.; Time 15.3.). Francis Fukuyama, jolla on kokemusta pieleen menneistä ennusteista, oli hänkin varovainen: "vielä on [...] aikaista sanoa, miten koronavirus tulee pitkällä aikavälillä vaikuttamaan yhteiskuntaan.” (YLE 22.3.) Filosofit, politiikan tutkijat ja yhteiskuntatieteilijät, talouden asiantuntijoista puhumattakaan, oli pääsääntöisesti helpompi houkutella ennustamaan (HS 19.3.; DN 31.5.; Economist 23.4.; Guardian 6.6.; SK 15.5.; Zeit 15.4.; YLE 18.4.).

Viidenneksi historiasta haettiin keinoja merkityksellistää, tarinallistaa ja sitä kautta jakaa kokemuksia. Erään suositun keinon tarjosi historiallinen kaunokirjallisuus. Runsaasti medianäkyvyyttä saivat esimerkiksi Boccaccion 1350-luvun alussa kirjoittama Decamerone ja Daniel Defoen vuonna 1722 ilmestynyt $A$ Journal of the Plague Year. Englanninkielinen media muisti myös Mary Shelleyn teoksen The Last Man (1826). Lähihistoriaa ja uudempaa epidemiakirjallisuutta edustivat Philip Rothin polioromaani Nemesis (2010) ja Hu Fayun SARS-romaani World@sars.come. Selvästi eniten kirjoitettiin kuitenkin Albert Camus'n romaanista Rutto (1947). Teoksen katsottiin tavoittavan jotain olennaista ja ajankohtaista yksilöiden moraalisista valinnoista ja keskinäisistä suhteista epidemian aikana. Ruton myyntiluvut alkoivat kivuta ylöspäin jo tammikuussa, Ruttovuodesta otettiin keväällä uusi painos, ja Decamerone nousi Amazonin eniten myytyjen italialaisten kirjojen joukkoon. (Guardian 1.5.; HS 17.3.; NYT 12.3., 19.3.; Zeit 18.3.; DN 3.3.; LRB 7.5.; Town and Country 16.3.; New Statesman 27.5.; Le Figaro 4.3.; Telegraph 20.3.)

Kuudenneksi korona-ajan historiapuheen voi ajatella palvelleen myös yksilöllisiä, psykologisia, jopa terapeuttisia tarpeita. Ihmisillä on tarve jakaa kokemuksiaan etenkin tilanteissa, joissa he kohtaavat uuden, tuntemattoman ja uhkaavan ilmiön. Kokemusten jakaminen puolestaan edellyttää - ja synnyttää - jaettuja merkityksiä ja tarinoita. (Merkityksellistäminen ei tarkoita samaa kuin tarkoituksen etsiminen pandemialle.) Koronapandemian tapauksessa tätä jaettua kokemusta haettiin myös historiasta, joskus vuosisatojen takaa. Media osallistui kertomalla miten menneisyyden ihmiset - todelliset tai fiktiiviset - ovat epidemioita kokeneet. (Zeit 02.7.; NYRB 25.3.; HS 31.5.; DN 15.3.; NYT 15.5.; 28.6.) Tarinat liittävät nykyisyyttä paitsi menneisyyteen myös tulevaisuuteen. Kuten talousnobelisti Robert J. Schiller muistutti New York Timesissa, korona-ajasta kerrotut tarinat tulevat osaltaan vaikuttamaan siihen, miten kriisistä toivutaan ja miten sen jälkeen toimitaan (29.5.).

\section{VIITTEET}

1 Koronan ensimmäisellä aallolla viitataan kevääseen ja kesään 2020. Kun puhumme "tautihistoriasta" tai “epidemiahistoriasta”, tarkoitamme nimenomaan äkillisiä, laajoja tartuntatautiepidemioita, vaikka epidemian käsite normaalisti on laajempi, "taudista" puhumattakaan.

2 Aineistoviittauksissa on mainittu lehden nimi ja päivämäärä,jolloin kyseinen artikkeli on julkaistu. Aineiston laajuudesta ja toisteisuudesta johtuen viittauksemme

siihen ovat pääosin esimerkinomaisia, eivät kattavia. Toimitus on vastaanottanut tekstin 14.9.2020.

3 Suomessa kriittisen puheenvuoron esitti professori Hanna Meretoja SK:een kirjoittamassaan puheenvuorossa: "Pandemia ei ole sota eikä potilas ole sotilas - lopettakaa ongelmallinen tarinallistaminen" (SK 1.5.2020).

4 Erinomainen esimerkki tästä: https://www.visualcapitalist.com/history-of-pandemics-deadliest/ 


\section{LEHDET JA UUTISSIVUSTOT}

The Atlantic

Conversation

Dagens Nyheter (DN)

Daily Mail

The Economist (Economist)

Le Figaro

Financial Times (FT)

Guardian UK (Guardian)

Helsingin Sanomat (HS)

Hufvudstadsbladet (HBL)

Helsingin Sanomien Kuukausiliite (HS Kuukausiliite)

London Review of Books (LRB)

National Geographic

New Statesman

New York Review of Books (NYRB)

New York Times (NYT)

PBS News Hour [uutissivusto] (PBS)

Suomen Kuvalehti (SK)

Telegraph

Time

Town and Country

YLE uutisten nettisivu (YLE)

Die Zeit

\section{KIRJALLISUUS}

Boccaccio, Giovanni (1983) Decamerone. Suom. Ilmari Lahti ja Vilho Hokkanen. Helsinki:Tammi. Kirjoitettu alun perin italiaksi 1350-luvun alussa.

Camus, Albert (1947) La peste. Paris: Gallimard.

Charters, Erica ja Richard A. MacKay (2020) "The history of science and medicine in the context of COVID-19". Spotlight Issue: Histories of epidemics in the time of COVID-19. Centaurus 62:2, 223-33.

Charters, Erica \& Koen Vermeir (toim.) (2020) Spotlight Issue: Histories of epidemics in the time of COVID-19. Centaurus 62:2, 219-380.

Correia,Sergio,Stephan Luck\&EmilVerner (2020)"Fight the Pandemic, Save the Economy: Lessons from the 1918 Flu”. Liberty Street Economics 27.3.2020. Osoitteessa https://libertystreeteconomics.newyorkfed. org/2020/03/fight-the-pandemic-save-the-economylessons-from-the-1918-flu.html Viitattu 9.9.2020.
Defoe, Daniel (2003/1722) A Journal of the Plague Year. London \& New York: Penguin Books.

Fayun, Hu (2011) Such Is This World@sars.come. Dobbs Ferry (NY): Ragged Banner Press.

Hatchett, Richard J., Carter E. Mecher \& Marc Lipsitch (2007)"Public Health Interventions and Epidemic Intensity during the 1918 Influenza Pandemic". Proceedings of the National Academy of Sciences 104: 18, 7582-87.

Crosby, Alfred W. (1976) Epidemic and Peace, 1918. Westport (CT): Greenwood Press.

Duffin, Jacalyn (2006) "Introduction: Lessons and Disappointments". Teoksessa Jacalyn Duffin ja Arthur Sweetman (toim.) SARS in Context: Memory, History, Policy. Montreal and Kingston: McGill-Queens's University Press, s. 1-18.

Honigsbaum, Mark (2020)"Revisiting the 1957 and 1968 influenza pandemics". Lancet 395 (June 13), 1824-26.

Jones, David S. (2020a) "History in a Crisis: Lessons for Covid-19". New England Journal of Medicine 382, 1681-83.

Jones, David S. (2020b) "COVID-19, history, and humility". Spotlight Issue: Histories of epidemics in the time of COVID-19. Centaurus 62:2, 370-80.

Markel, Howard ym. (2007) "Nonpharmaceutical Interventions Implemented by US Cities During the 19181919 Influenza Pandemic". Journal of the American Medical Association 298:6, 644-56.

History of Outbreaks Collection (2020) Oxford University Press. Osoitteessa https://academic.oup.com/journals/ pages/history_of_outbreaks Viitattu 9.9.2020.

Rosenberg, Charles E. (1989) "What is an epidemic? AIDS in historical perspective". Daedalus 188:2,1-17.

Roth, Philip (2010) Nemesis. New York: Houghton Mifflin.

Shelley, Mary Wollstonecraft (1826) The Last Man. London: Henry Colburn.

Strasser, Bruno J. \& Thomas Schlich (2020) "A history of the medical mask and the rise of throwaway culture". The Lancet 396 (July 4), 19-20.

Wallis, Patrick ym. (2020) Epidemics, Disease and Mortality in Economic History. Special Issue of Economic History Review 73:3. Osoitteessa https://onlinelibrary.wiley. com/doi/toc/10.1111/(ISSN)1468-0289.epidemicsdisease-mortality Viitattu 9.9.2020.

White, Alexandre (2020) "Historical linkages: Epidemic threat, economic risk, and xenophobia". Lancet 395 (April 18), 1250-51. 